\title{
Cost Accounting Skills Needs of Small Business 0perators
}

\author{
Anthonia Uju Umeji, Chiaka Augusta Obi \\ Department of Vocational Teacher Education, University of Nigeria, Nsukka, Nigeria \\ Email: anthonia.umeji@unn.edu.ng
}

Received 18 February 2014; revised 18 March 2014; accepted 30 March 2014

Copyright (C) 2014 by authors and Scientific Research Publishing Inc.

This work is licensed under the Creative Commons Attribution International License (CC BY). http://creativecommons.org/licenses/by/4.0/

(c) (i) Open Access

\section{Abstract}

The major purpose of the study was to determine the record-keeping, inventory control and price determination skills needs of small business operators in Anambra State. Three research questions and two null hypotheses were used to attain this purpose. A descriptive survey research design was adopted in the study which involved 280 registered small business operators in the state. Due to the manageable size of the population, all the 280 registered small business operators were surveyed. Therefore there was no sampling. Data were collected with the help of three research assistants using structured Cost Accounting Skills Needs (CASNs) questionnaire with 43-item statements. The questionnaire was divided into four sections (A - D). Section A was used to obtain the personal data of the respondents. Sections B, C and D carried a bipolar scale of perceived importance and expressed possession to obtain the respondents' ratings of the skills (record-keeping, inventory control and price determination skills). The instrument was validated by three experts. Cronbach Alpha reliability technique was used to determine the internal consistency of the instrument. Reliability coefficient of $0.78,0.83$ and 0.75 were obtained for record-keeping, inventory control and price determination skills respectively. Data from 269 copies returned were used for data analysis. Analysis was done using mean and correlated t-test at 0.05 level of significance to answer the research questions while analysis of variance was used to test the two null hypotheses. The study found that record-keeping, inventory control and price determination skills were perceived to be very important by the operators, but the levels of possession were still below expectation. Based on these findings, the study recommended that a training programme be mounted for small business operators in the state on record-keeping and inventory control skills needed for business operation.

\section{Keywords}

Cost Accounting, Record-Keeping, Inventory Control, Price Determination 


\section{Introduction}

Ever since the use of money replaced barter, people have been concerned with cost. Barter system was purely on exchange of goods for goods and services for services. Cost as defined by the Institute of Costs and Management Accountants (ICMA), now known as the Chartered Institute of Management Accountants (CIMA) London, as opined by Murthy and Gurusamy [1], is the amount of actual expenditure incurred on a given thing and notional expenditure incurred on a given thing. Accounting for costs is an indispensable tool for business survival. Record-keeping and Inventory Control are components of cost accounting. Cost accounting is branch of accounting that provides management or owners of business with information needed for decision making. Business organizations need cost accounting information to make informed decisions relating to what product to make or sell, how much profit or benefit that should be generated, cost price and selling price of items and even items that are not profitable. Furthermore, studying cost accounting is one of the best business investments that operators can make. Horngren, Datar, Foster, Rajan and Ittner [2] stated that, success in any business from the smallest corner store to the largest multi-national corporation requires the use of cost accounting.

Cost accounting as defined by Murthy and Gurusamy [1] is the process of accounting for costs, which begins with recording of income and expenditure on the basis of which they are calculated and ends with the preparation of periodical statements and reports for ascertaining and controlling costs. This definition is used in this study. Cost accounting usually starts from recording or maintaining accounting books from diverse sources. Baumback [3] stated that some knowledge of cost accounting skills is needed in almost every business operation. Ndulue [4] observed that most business units in the developing countries do not keep proper accounting books or proper accounting records of their business. Cost Accounting process involves record-keeping, and inventory control. Record-keeping and inventory control have been identified for the purpose of this study.

Record-keeping as defined in Australian Standard on Management is the making and maintaining of complete, accurate and reliable evidence of business transactions in the form of recorded information. Dun and Bradstreet in Osuala [5] noted that, there is a correlation between inadequate records and business failures. The operators of businesses inability to keep adequate records constitute a major problem. Therefore reliable records are not only important for financial management, planning and control, but are critical to the survival of the business. Again many business owners are unaware of their business financial status and, therefore, are unable to make sound decisions because of inadequate record-keeping or failure to keep up to date records [6]. Record keeping is an indispensable business tool used in monitoring not only business performance but also its inventory control. Inventory simply means the goods and services that businesses hold in stock. Inventory could be defined as the total amount of goods and or materials contained in a store or a factory at any given time [7]. Inventory control therefore means keeping the overall costs associated with having inventory as low as possible without creating problems for customer satisfaction [8].

In addition, insufficient inventory levels cause problem because shortages and stock outs occur and customers become disillusioned and fail to return [9]. Since the largest investment that any business must make is in inventory, business operators should be able to control the inventory levels so as not to be too high or too low. Inventory control is one of the most neglected of all the management responsibilities. Osuala [10] also pointed out that a more common situation is not only acquiring too much inventory, but also too much of the wrong type of inventory. Many businesses have an excess amount of working capital tied up in an accumulation of needless inventory. Carrying excess inventory will also result in excess carrying cost and excess cost of holding them and thereby resulting in either reduced profit or not making profit at all.

Price is a major element in profit determination and an important aspect of cost accounting. Pricing a product simply means establishing a selling price for a product. No matter the type of product or service, the price charged to customers or clients will have a direct effect on the success of the business. Osuala [11] defined price as the amount of money which is needed to acquire in exchange of some goods and services. Price as defined by Modern in Asuquo [12] is the value or sum of money which business organisation agrees to carry out an exchange of transaction. Hasty and Reardon still in Asuquo defined price as the value assigned to something bought, sold or offered for sale expressed in monetary terms. Furthermore, Kotler and Armstrong [13] defined price as the amount of money that customers have to pay to obtain the product.

Price is a very important factor that determines whether a profit is to be made or not. Businesses who wish to set prices effectively, must determine the role of price in profit determination. Osuala [10] defined profit as the net increase over a period of time in cash or capital cycled through the business and it indicates how effectively 
the business is being managed over time. Bessong [7] stated that if the price of a product or service does not cover costs, cash flow will be cumulatively negative and will exhaust financial resources and in turn cause failure. Ndulue [4] observed that small business units in the developing countries do not have what it takes to own a successful business in terms of skills and knowledge. Similarly, Obi [14] noted that many small business operators do not have most of the entrepreneurial skills required for running a business. The author explained further that lack of skills affects the management of the business and subsequently the profit. Researchers agreed that inventory valuation and good product pricing are inevitable for business survival [15].

Cost accounting provides techniques and methods of controlling inventory. It has been observed that small business units in the developing countries do not have what it takes to own a successful business in terms of skills and knowledge.

Skill is imperative for good record-keeping and inventory control. According to Obi [14], skill is the ability to use one's knowledge effectively and readily in performing an act, or a habit of doing a particular thing competently. Nnachi [16] refers to skill as the ability to perform well in a task as a result of exposure, training or practice. The author explained that an individual may hardly be skilled in a task without exposure, training or practice. In line with the above analysis, this study seeks to determine cost accounting skill needs of small business operators. Business may be referred to as an organisation that produces or distributes goods and services. Ayozie [17] defined business as efforts of people to produce and distribute the goods and services that are requisite for their well being, comfort, safety and happiness and which are of benefit to society as a whole. Adekola [18] referred to a business as an occupation, work, or trade in which a person is engaged. A person who is engaged in a business is usually referred to as a business operator. Summer [19] defined a business operator as a person or organisation that operates a particular business.

Furthermore, businesses are classified in most countries as micro, small, medium and large businesses. This classification reflects the way that businesses are clustered according to selected criteria and ensures grouping of businesses with similar characteristics such as size or type of product or service [9]. The definition of what constitutes a small business for all practical purposes defies precision. This is because what is considered a small business in one economy may be regarded as a medium or large scale business in another economy. Oyekanmi [20] stated that, there is no universally accepted definition of small business in Africa. The author buttressed that even definitions in other countries lack uniformity and reflect the relative development of the respective economies.

In Nigeria, the National Council of Industries (NCI) defined small business as an industry with a labour size of 11 - 100 workers or a total cost of not more than N50 million, including working capital but excluding cost of land. Medium industry on the other hand refers to an industry with a labour size of between $101-300$ workers or a total cost of over N50 million but not more than N200 million including working capital but excluding cost of land [21]. Central Bank of Nigeria (CBN) defined small scale business in line with the definition given by the National Council on Industry. Both asserted that a small business is an enterprise with a labour size of between 11 - 100 workers or a cost of between N1.5 - N50 million including working capital but excluding cost of land. Both also defined medium scale business as an enterprise with a labour size of between 101 and 300 or a cost between N50 - N200 million excluding cost of land [22]. This study adopts the definitions given by NCI and CBN. This is because the definition is relatively more accommodating and will allow the majority of small scale business the opportunity to participate in any programme designed for SMEs.

Small scale industries have been recognized by governments and development experts as the main engine of economic growth and a major factor in promoting private sector development and partnership. Udechukwu [23] posited that the development of small scale industries is an essential element in the growth strategy of most economies and holds particular significance for Nigeria. Nigerian government has advanced loan facilities to small and medium scale businesses through establishments, or agencies created for the purpose. These include, the Nigerian Bank for Commerce and Industry (NBCI), Small Scale Industries Credit Scheme established under the third National Development Plan, National Economic Reconstruction Fund (NERFUND) and Family Economic Advancement Programme (FEAP) was also established as the micro-credit scheme geared towards investment promotion and poverty alleviation in the various local governments in Nigeria [23].

Despite all the assistance by the government, small scale businesses still fail. Osuala [9] stated that a prospective small business manager should have adequate technical ability, sufficient conceptual ability to visualize, coordinate and integrate the various operations of the business into a synergistic whole. The operators of small business should possess skills needed to propel the business to higher level of performance. In Nigeria, small 
business operators face a lot of constraints that limit their growth and survival. Osuala further stated other controllable factors causing business failures as: lack of experience, inappropriate location, lack of inventory control, improper pricing and inexperience in record-keeping among others. Scott [24] opined that successful operation of small business requires that operators should possess diverse range of skills. The author submitted that accounting skills are fundamental in every business operation.

Similarly, Obi [14] stated that managers of businesses should possess skills in accounting, marketing, and personnel management. The author stated that, there are few people who would undertake to train for the acquisition of these skills and practice them. Obviously, no single research work will capture all the business skills mentioned above. Hence, the thrust of this study, therefore, is to determine the record-keeping and inventory controls skill needs of small business operators in Anambra State. This study is informed for the fact that researchers have recommended that good record-keeping, inventory control, inventory valuation and price determination are imperative for business survival. These are various components of cost accounting which require that operators should possess skills in practicing them.

\section{Purpose of the Study}

The major purpose of this study was to determine the record-keeping and inventory control skill needs of small business operators in Anambra State. Specifically, the study sought to determine:

1) The perceived level of importance and expressed level of possession of record-keeping skills by small business operators.

2) The perceived level of importance and expressed level of possession of inventory control skills by small business operators.

3) The perceived level of importance and expressed possession of price determination skills by small business operators.

\section{Research Questions}

The following research questions based on the specific purposes were formulated to guide the study:

1) What are the perceived level of importance and expressed possession of record-keeping skills by small business operators in Anambra State?

2) What are the perceived level of importance and expressed possession of inventory control skills by small business operators in Anambra State?

3) What are the perceived level of importance and expressed possession of price determination skills by small business operators in Anambra state?

\section{Hypotheses}

$\mathrm{HO}_{1}$ : Educational Qualification is not a significant source of difference on the perceived importance and expressed possession of recordkeeping skills, inventory control skills and price determination skills by small business operators.

$\mathrm{HO}_{2}$ : Years of Experience is not a significant source of difference on the perceived importance and expressed possession of record keeping skills, inventory control skills and price determination skills by small business operators.

\section{Methodology}

A survey research design was adopted for the study. The area of study was Anambra State. The population for the study was 280 registered small business operators. The population for the study was obtained from Anambra State Ministry of Commerce and Industry Awka (SME unit).

Two research questions were formulated to guide the study. A 31-item structured Record-Keeping and Inventory Control Skill Needs (RISN) questionnaire divided into three sections with a bi-polar scale was used for the collection of data. Section A focused on personal information of the respondents. Section B focused on perceived level of importance and expressed possession of record-keeping skill by small business operators. Section B focused on perceived level of importance and expressed possession of inventory control skills by small business operators. 
The response categories for questionnaire items in section $\mathrm{B}$ and $\mathrm{C}$ along with their numerical values are as follows Very Highly possessed/important $=5$, Highly possessed/important $=4$, Averagely possessed/important $=3$, Possessed a little/important $=2$, Not possessed/important $=1$.

The questionnaire was subjected to face validation by three experts, one from Internal Audit Unit, University of Nigeria, Nsukka and two from the department of Vocational Teacher Education, University of Nigeria, and Nsukka. The reliability of the instrument was established using Cronbach Alpha and the reliability coefficient of 0.81 was obtained.

Copies of the questionnaire were administered to the respondents with the help of three research assistants. The research assistants were briefed on how to administer and collect the questionnaire. The data generated in the study were analysed based on the research questions and hypotheses that guided the study.

The results revealed that the ability to post transactions to various accounting books as they occur, obtained the highest mean score of 4.61 with a standard deviation of 0.58 . On the other hand, the ability to use bin cards to record stock movement was rated lowest by the respondents $(\mathrm{x}=4.23$; $\mathrm{SD}=0.87)$.

The analysis of variance (ANOVA) presented in Table 1 above revealed that the F-ratio values of 11 out of 15 items were between 3.08 - 7.63 which are all greater than the F-critical value of 3.00 at 0.05 level of significance. This implied that, there are significant differences in the mean ratings of the respondents with SSCE/ NECO, ND/NCE and HND/B.Sc qualifications on the 11 record-keeping skills by the operators. The result clearly showed that those operators with HND/B.Sc possessed more record-keeping skills than others. Therefore, the null hypothesis of no significant difference was rejected. This was further strengthened by the result of the post hoc test.

Results in Table 2 showed that the ability to calculate the lead time to determine the period of reordering of stock, obtain the highest mean score of 4.58 with a standard deviation of 0.73 . On the other hand, the ability to place order for moving inventory and at the right quantity and quality was rated lowest by the respondents $(\mathrm{x}=$ $4.05 ; \mathrm{SD}=0.85)$.

Table 1. Mean scores, standard deviation and analysis of variance (ANOVA) of ratings of small business operators on perceived importance and expressed possession of record-keeping skills according to educational qualification.

\begin{tabular}{|c|c|c|c|c|c|c|c|c|c|}
\hline \multirow[t]{2}{*}{$\mathbf{S} / \mathbf{N}$} & \multirow[t]{2}{*}{ Skill Statement } & \multicolumn{2}{|c|}{$\begin{array}{l}\text { Perceived } \\
\text { Importance }\end{array}$} & \multicolumn{2}{|c|}{$\begin{array}{l}\text { Expressed } \\
\text { Possession }\end{array}$} & \multirow[t]{2}{*}{ F-Ratio } & \multirow[t]{2}{*}{ F-Critical } & \multirow[t]{2}{*}{ HO } & \multirow{2}{*}{$\begin{array}{c}\text { Post Hoc } \\
\text { Test } \\
\text { (scheffe) }\end{array}$} \\
\hline & & X1 & SD1 & $\mathrm{X} 2$ & SD2 & & & & \\
\hline 1 & Use double entry to record transactions & 4.37 & 0.73 & 2.99 & 1.17 & 5.22 & 3 & s & HND/B.Sc \\
\hline 2 & Record all transaction in the cash book & 4.37 & 0.85 & 2.27 & 1.08 & 3.82 & 3 & s & $\mathrm{ND} / \mathrm{NCE}$ \\
\hline 3 & $\begin{array}{l}\text { Debit cash sales in the cash book and post entry to a } \\
\text { credit side of the ledger }\end{array}$ & 4.43 & 0.73 & 2.43 & 0.98 & 7.63 & 3 & $\mathrm{~s}$ & HND/B.Sc \\
\hline 4 & $\begin{array}{l}\text { Credit cash purchases in the cash book and debit ledger } \\
\text { account }\end{array}$ & 4.47 & 0.74 & 2.44 & 0.72 & 0.19 & 3 & Ns & \\
\hline 5 & Record credit sales in the sales daybook & 4.43 & 0.79 & 3.09 & 0.91 & 4.56 & 3 & s & HND/B.Sc \\
\hline 6 & Post the sundry sales to ledger & 4.37 & 0.79 & 2.52 & 4.35 & 3.17 & 3 & $\mathrm{~s}$ & HND/B.Sc \\
\hline 7 & $\begin{array}{l}\text { Record goods purchased on credit in the purchases } \\
\text { daybook }\end{array}$ & 4.52 & 0.73 & 3.85 & 0.79 & 1.69 & 3 & Ns & \\
\hline 8 & Post the sundry purchases in the ledger account & 4.29 & 0.83 & 1.93 & 0.57 & 4.26 & 3 & $\mathrm{~S}$ & HND/B.Sc \\
\hline 9 & $\begin{array}{l}\text { Use return inwards book to record goods returned by } \\
\text { customer }\end{array}$ & 4.48 & 0.73 & 2.47 & 1.12 & 0.25 & 3 & Ns & \\
\hline 10 & $\begin{array}{l}\text { Enter transactions to subsidiary books from source } \\
\text { documents }\end{array}$ & 4.57 & 0.59 & 2.98 & 0.86 & 5.74 & 3 & $\mathrm{~s}$ & HND/B.Sc \\
\hline 11 & Post items to ledger applying double entry principle & 4.38 & 0.79 & 3.76 & 0.72 & 3.73 & 3 & s & HND/B.Sc \\
\hline 12 & Maintain store ledger account & 4.33 & 0.78 & 2.34 & 0.92 & 6.62 & 3 & s & HND/B.Sc \\
\hline 13 & Use bin card to record stock movement & 4.23 & 0.87 & 2.33 & 0.96 & 3.08 & 3 & $\mathrm{~S}$ & ND/NCE \\
\hline 14 & $\begin{array}{l}\text { Record goods sent back to suppliers in the return } \\
\text { outward book }\end{array}$ & 4.47 & 0.67 & 2.51 & 0.85 & 0.39 & 3 & Ns & \\
\hline 15 & $\begin{array}{l}\text { Post transactions to various accounting books as they } \\
\text { occur }\end{array}$ & 4.61 & 0.58 & 3.03 & 0.80 & 3.82 & 3 & $\mathrm{~s}$ & HND/B.Sc \\
\hline
\end{tabular}

F-tab $=3.00, \mathrm{df}=2$ and 266, $\mathrm{P}>0.05$. 
Table 2. Mean scores, standard deviation and analysis of variance (ANOVA) of ratings of small business operators on perceived importance and expressed possession of inventory control skills according to educational qualification.

\begin{tabular}{|c|c|c|c|c|c|c|c|c|c|}
\hline \multirow[t]{2}{*}{$\mathbf{S} / \mathbf{N}$} & \multirow[t]{2}{*}{ Skill Statement } & \multicolumn{2}{|c|}{$\begin{array}{l}\text { Perceived } \\
\text { Importance }\end{array}$} & \multicolumn{2}{|c|}{$\begin{array}{l}\text { Expressed } \\
\text { Possession }\end{array}$} & \multirow[t]{2}{*}{ F-Ratio } & \multirow[t]{2}{*}{ F-Critical } & \multirow[t]{2}{*}{ HO } & \multirow{2}{*}{$\begin{array}{c}\text { Post Hoc } \\
\text { Test } \\
\text { (scheffe) }\end{array}$} \\
\hline & & $\mathbf{X 1}$ & SD1 & $\mathrm{X} 2$ & SD2 & & & & \\
\hline 1 & Calculate the minimum stock level to avoid stock out & 4.42 & 0.08 & 2.67 & 0.89 & 5.77 & 3 & $\mathrm{~s}$ & HND/B.Sc \\
\hline 2 & $\begin{array}{l}\text { Calculate the maximum stock level to determine } \\
\text { economic order quantity }\end{array}$ & 4.39 & 0.79 & 2.38 & 0.89 & 3.56 & 3 & $\mathrm{~s}$ & ND/NCE \\
\hline 3 & $\begin{array}{l}\text { Calculate the reorder level of stock to determine the } \\
\text { maximum usage of stock }\end{array}$ & 4.29 & 0.87 & 1.95 & 0.87 & 0.35 & 3 & Ns & \\
\hline 4 & $\begin{array}{l}\text { Calculate the lead time to determine the period of } \\
\text { reordering of stock }\end{array}$ & 4.58 & 0.73 & 2.85 & 0.85 & 8.43 & 3 & $\mathrm{~s}$ & HND/B.Sc \\
\hline 5 & $\begin{array}{l}\text { Use carrying cost and reordering cost to calculate the } \\
\text { total cost of stock }\end{array}$ & 4.48 & 0.57 & 2.37 & 1 & 1.46 & 3 & Ns & \\
\hline 6 & $\begin{array}{l}\text { Period stock taking to determine the quantity of items } \\
\text { in the store }\end{array}$ & 4.33 & 0.78 & 2.37 & 1.16 & 5.52 & 3 & $\mathrm{~s}$ & HND/B.Sc \\
\hline 7 & $\begin{array}{l}\text { Use continuous stock taking to determine the quantity } \\
\text { of items in the store }\end{array}$ & 4.43 & 0.66 & 3.97 & 0.99 & 7 & 3 & $\mathrm{~s}$ & HND/B.Sc \\
\hline 8 & Use good storage facilities to store inventories & 4.19 & 0.79 & 2.46 & 0.73 & 3.46 & 3 & $\mathrm{~s}$ & ND/NCE \\
\hline 9 & $\begin{array}{l}\text { Place order for moving inventory at the right quantity } \\
\text { and quality }\end{array}$ & 4.05 & 0.85 & 1.97 & 0.79 & 4.54 & 3 & $\mathrm{~s}$ & HND/B.Sc \\
\hline 10 & Keep buffer stock to avoid the lost of customers & 4.53 & 0.58 & 2.38 & 0.86 & 1.4 & 3 & Ns & \\
\hline 11 & Record the issuance and usage of inventory & 4.33 & 0.78 & 1.94 & 1.04 & 2.6 & 3 & Ns & \\
\hline 12 & Calculate carrying cost to minimize lost & 4.52 & 0.79 & 3.52 & 0.97 & 11.07 & 3 & $\mathrm{~s}$ & HND/B.Sc \\
\hline 13 & $\begin{array}{l}\text { Set inventory prices as low as possible to attract } \\
\text { customers }\end{array}$ & 4.48 & 0.5 & 2.45 & 0.59 & 6.92 & 3 & $\mathrm{~s}$ & HND/B.Sc \\
\hline 14 & $\begin{array}{l}\text { Take physical count of inventory to manage } \\
\text { deterioration and obsolesce }\end{array}$ & 4.52 & 0.5 & 1.91 & 0.56 & 3.57 & 3 & $\mathrm{~s}$ & $\mathrm{ND} / \mathrm{NCE}$ \\
\hline 15 & Store moving inventory to minimize holding cost & 4.38 & 0.66 & 2.49 & 0.66 & 0.55 & 3 & Ns & \\
\hline 16 & Frequent check of stock to prevent and control fraud & 4.28 & 0.63 & 2.51 & 0.69 & 3.48 & 3 & $\mathrm{~S}$ & HND/B.Sc \\
\hline
\end{tabular}

F-tab $=3.00, \mathrm{df}=2$ and 266, $\mathrm{P}>0.05$.

The analysis of variance (ANOVA) presented in Table 2 above revealed that the F-ratio values of 11 out of 16 items were between 3.46 - 11.07 which are all greater than the F-critical value of 3.00 at 0.05 level of significance. This indicated that, there are significant differences in the mean ratings of the responses of the small business operators with SSCE/NECO, ND/NCE and HND/B.Sc qualification on the inventory control skills possessed by the operators. Therefore, the null hypothesis of no significant difference was rejected.

The result of the Post Hoc test for the 11 items that are significant further showed that the sources of difference are small business operators with HND/B.Sc qualification. This implied that business operators with HND/B.Sc qualification possessed skills items 1, 4, 6, 7, 9, 12, 13 and 16 better than others.

The data presented in Table 3 showed that the ability to calculate selling price by deducting the discount allowed to arrive at agreed invoice price obtained the highest score of 4.62 with a standard deviation of 0.57 . On the other hand, the ability to add direct wages to determine prime cost was rated lowest by the respondents $(\mathrm{x}=$ 4.04; $\mathrm{SD}=0.50)$. The result further revealed that all the twelve (12) price determination skills were important for small business operation.

The analysis of variance (ANOVA) presented in Table 3 above showed that the F-ratio values of 9 out of 12 items were between 3.21 - 12.07 which are all greater than the F-critical value of 3.00 at 0.05 level of significance. This showed that, there are significant differences in the mean ratings of the respondents with SSCE/ NECO, ND/NCE and HND/B.Sc qualification on the 9 price determination skills possessed by the operators. Therefore, the null hypothesis of no significant difference for the 9 items was rejected.

The results revealed that the ability to post transactions to various accounting books as they occur, obtained the highest mean score of 4.61 with a standard deviation of 0.58 . On the other hand, the ability to use bin cards 
Table 3. Mean scores, standard deviation and analysis of variance (ANOVA) of ratings of small business operators on perceived importance and expressed possession of price determination skills according to educational qualification.

\begin{tabular}{|c|c|c|c|c|c|c|c|c|c|}
\hline \multirow[t]{2}{*}{$\mathrm{S} / \mathbf{N}$} & \multirow{2}{*}{ Skill Statement } & \multicolumn{2}{|c|}{$\begin{array}{l}\text { Perceived } \\
\text { Importance }\end{array}$} & \multicolumn{2}{|c|}{$\begin{array}{l}\text { Expressed } \\
\text { Possession }\end{array}$} & \multirow{2}{*}{ F-Ratio } & \multirow{2}{*}{ F-Critical } & \multirow[t]{2}{*}{ HO } & \multirow{2}{*}{$\begin{array}{c}\text { Post Hoc } \\
\text { Test } \\
\text { (scheffe) }\end{array}$} \\
\hline & & X1 & SD1 & $\mathbf{X} 2$ & SD2 & & & & \\
\hline 1 & Calculate cost per unit of item & 4.35 & 0.66 & 2.48 & 0.9 & 6.37 & 3 & s & HND/B.Sc \\
\hline 2 & Calculate the total cost of product or service & 4.34 & 0.68 & 2.5 & 0.85 & 10.39 & 3 & s & HND/B.Sc \\
\hline 3 & Compute prime cost by adding direct costs & 4.23 & 0.87 & 3.79 & 0.68 & 3.51 & 3 & s & $\mathrm{ND} / \mathrm{NCE}$ \\
\hline 4 & $\begin{array}{l}\text { Calculate overheads by subtracting the sum of factory, } \\
\text { administrative, selling and distribution expenses from } \\
\text { total cost }\end{array}$ & 4.35 & 0.63 & 2.36 & 0.73 & 0.91 & 3 & Ns & \\
\hline 5 & Add direct wages to determine prime cost & 4.04 & 0.5 & 2.89 & 0.82 & 4.24 & 3 & s & $\mathrm{HND} / \mathrm{B} . \mathrm{Sc}$ \\
\hline 6 & $\begin{array}{l}\text { Calculate profit or loss by subtracting the cost of sale } \\
\text { from total sales }\end{array}$ & 4.33 & 0.71 & 2.51 & 0.85 & 0.39 & 3 & Ns & \\
\hline 7 & $\begin{array}{l}\text { Identify and allocate direct cost by adding direct and } \\
\text { indirect materials, wages indirect expenses }\end{array}$ & 4.52 & 0.5 & 2.61 & 0.91 & 9.19 & 3 & s & HND/B.Sc \\
\hline 8 & $\begin{array}{l}\text { Aggregate direct material cost, direct wages and direct } \\
\text { expenses to arrive at prime cost }\end{array}$ & 4.28 & 0.69 & 2.18 & 1.05 & 3.22 & 3 & $\mathrm{~s}$ & HND/B.Sc \\
\hline 9 & $\begin{array}{l}\text { Aggregate indirect material cost, indirect wages and } \\
\text { indirect expenses to arrive at overhead cost }\end{array}$ & 4.17 & 0.5 & 3.96 & 1.14 & 12.07 & 3 & s & HND/B.Sc \\
\hline 10 & Calculate the selling price using mark-up system & 4.52 & 0.5 & 2.2 & 1.03 & 3.21 & 3 & s & HND/B.Sc \\
\hline 11 & $\begin{array}{l}\text { Calculate the selling price by deducting the discount } \\
\text { allowed to arrive at agreed invoice price }\end{array}$ & 4.62 & 0.57 & 2.42 & 0.96 & 1.01 & 3 & Ns & HND/B.Sc \\
\hline 12 & $\begin{array}{l}\text { Subtract selling expenses from gross profit to arrive at } \\
\text { net profit }\end{array}$ & 4.57 & 0.66 & 2.44 & 0.7 & 4.24 & 3 & s & HND/B.Sc \\
\hline
\end{tabular}

to record stock movement was rated lowest by the respondents $(\mathrm{x}=4.23$; $\mathrm{SD}=0.87)$.

The analysis of variance (ANOVA) presented in Table 4 above showed that the F-ratio values of 10 out of 15 items were between 3.21 - 15.30 which are all greater than the F-critical value of 3.00 at 0.05 level of significance. This implied that, there are significant differences in the mean ratings of the responses of the small business operators with 1 - 5 years, 6 - 10 years and above 10 years of experience on the 10 record keeping skills possessed. The result clearly revealed that operators with 6 - 10 years of experience possess more record keeping skills than those with 1 - 5 years of experience. Ayozie (2005) noted that a good number of small business fail in the first one to five years of start-up. Therefore, the null hypothesis of no significant difference was rejected.

The result of the Post Hoc test for the 10 items that are significant revealed that the source of difference for items 1, 2, 3, 6, 10, 12, 13 and 15 are small business operators with above 10 years of business experience. This implied that business operators of above 10 years of experience possessed record-keeping skill items 1,2 , 3, 6 , 10, 12, 13 and 15 better than others. The source of difference for items 4 and 8 are small business operators with 6 - 10 years of business experience. This means that business operators with 6 - 10 years of experience possessed record-keeping skills for items 4 and 8 better than others.

Results in Table 5 showed that the ability to calculate the lead time to determine the period of reordering of stock, obtain the highest mean score of 4.58 with a standard deviation of 0.73 . On the other hand, the ability to place order for moving inventory and at the right quantity and quality was rated lowest by the respondents $(\mathrm{x}=$ 4.05; SD = 0.85).

The analysis of variance (ANOVA) presented in Table 5 above showed that the F-ratio values of 10 out of 16 items were between 3.25 - 27.87 which are all greater than the F-critical value of 3.00 at 0.05 level of significance. This indicated that, there are significant differences in the mean ratings of the responses of the small business operators with 1 - 5 years, 6 - 10 years and above 10 years of experience on the 10 inventory control skills possessed by the operators. Therefore, the null hypothesis of no significant difference was rejected.

On the other hand, the F-ratio values of the remaining six items, specifically items $2,3,5,7,8$, and 15 are 2.63, 1.54, $0.56,1.57,1.68$ and 1.16 respectively which are less than the F-critical value of 3.00 at 0.05 level of 
Table 4. Mean scores, standard deviation and analysis of variance (ANOVA) of ratings of small business operators on perceived importance and expressed possession of record-keeping skills according to years of experience.

\begin{tabular}{|c|c|c|c|c|c|c|c|c|c|}
\hline \multirow[t]{2}{*}{$\mathbf{S} / \mathbf{N}$} & \multirow{2}{*}{ Skill Statement } & \multicolumn{2}{|c|}{$\begin{array}{c}\text { Perceived } \\
\text { Importance }\end{array}$} & \multicolumn{2}{|c|}{$\begin{array}{l}\text { Expressed } \\
\text { Possession }\end{array}$} & \multirow[t]{2}{*}{ F-Ratio } & \multirow{2}{*}{ F-Critical } & \multirow{2}{*}{ HO } & \multirow{2}{*}{$\begin{array}{l}\text { Post Hoc Test } \\
\text { (scheffe) }\end{array}$} \\
\hline & & $\mathbf{X 1}$ & SD1 & $\mathrm{X} 2$ & SD2 & & & & \\
\hline 1 & Use double entry to record transactions & 4.37 & 0.73 & 2.99 & 1.17 & 3.66 & 3 & $\mathrm{~S}$ & Above 10 yrs \\
\hline 2 & Record all transaction in the cash book & 4.37 & 0.85 & 2.27 & 1.08 & 4.43 & 3 & $\mathrm{~s}$ & Above 10 yrs \\
\hline 3 & $\begin{array}{l}\text { Debit cash sales in the cash book and post entry to a } \\
\text { credit side of the ledger }\end{array}$ & 4.43 & 0.73 & 2.43 & 0.98 & 3.46 & 3 & $\mathrm{~s}$ & Above 10 yrs \\
\hline 4 & $\begin{array}{l}\text { Credit cash purchases in the cash book and debit ledger } \\
\text { account }\end{array}$ & 4.47 & 0.74 & 2.44 & 0.72 & 3.21 & 3 & $\mathrm{~S}$ & $6-10$ yrs \\
\hline 5 & Record credit sales in the sales daybook & 4.43 & 0.79 & 3.09 & 0.91 & 0.65 & 3 & Ns & \\
\hline 6 & post the sundry sales to ledger & 4.37 & 0.79 & 2.52 & 4.35 & 15.3 & 3 & $\mathrm{~S}$ & Above 10 yrs \\
\hline 7 & $\begin{array}{l}\text { Record goods purchased on credit in the purchases } \\
\text { daybook }\end{array}$ & 4.52 & 0.73 & 3.85 & 0.79 & 2.67 & 3 & Ns & \\
\hline 8 & Post the sundry purchases in the ledger account & 4.29 & 0.83 & 1.93 & 0.57 & 12.46 & 3 & $\mathrm{~S}$ & $6-10 \mathrm{yrs}$ \\
\hline 9 & $\begin{array}{l}\text { Use return inwards book to record goods returned by } \\
\text { customer }\end{array}$ & 4.48 & 0.73 & 2.47 & 1.12 & 0.42 & 3 & Ns & \\
\hline 10 & $\begin{array}{l}\text { Enter transactions to subsidiary books from source } \\
\text { documents }\end{array}$ & 4.57 & 0.59 & 2.98 & 0.86 & 8.85 & 3 & $\mathrm{~s}$ & Above 10 yrs \\
\hline 11 & Post items to ledger applying double entry principle & 4.38 & 0.79 & 3.76 & 0.72 & 1.65 & 3 & Ns & \\
\hline 12 & Maintain store ledger account & 4.33 & 0.78 & 2.34 & 0.92 & 11.85 & 3 & $\mathrm{~s}$ & Above 10 yrs \\
\hline 13 & Use bin card to record stock movement & 4.23 & 0.87 & 2.33 & 0.96 & 11.26 & 3 & $\mathrm{~S}$ & Above 10 yrs \\
\hline 14 & $\begin{array}{l}\text { Record goods sent back to suppliers in the return } \\
\text { outward book }\end{array}$ & 4.47 & 0.67 & 2.51 & 0.85 & 0.67 & 3 & Ns & \\
\hline 15 & $\begin{array}{l}\text { post transactions to various accounting books as they } \\
\text { occur }\end{array}$ & 4.61 & 0.58 & 3.03 & 0.8 & 7.09 & 3 & $\mathrm{~s}$ & HND/B.Sc \\
\hline
\end{tabular}

F-tab $=3.00, \mathrm{df}=2$ and 266, $\mathrm{P}>0.05$.

significance, indicating that there are no significant differences in the mean ratings of the responses of the small business operators with 1 - 5 years, 6 - 10 years and above 10 years of experience on the six inventory control skills possessed by the operators. Therefore, the null hypothesis of no significant difference was accepted.

The result of the Post Hoc test for the 10 items that are significant revealed that the source of difference for items 4, 6, 10, 11, 12, 13 and 16 are small business operators with above 10 years of business experience. This implied that business operators of above 10 years of experience possessed inventory control skill items 4, 6, 10, 11, 12, 13 and 16 better than others. The source of difference for items 1, 9 and 14 are small business operators with 6 - 10 years of business experience. This means that business operators with 6 - 10 years of experience possessed the inventory control skill items 1, 9 and 14 better than others.

The data presented in Table 6 showed that the ability to calculate selling price by deducting the discount allowed to arrive at agreed invoice price obtained the highest score of 4.62 with a standard deviation of 0.57 . On the other hand, the ability to add direct wages to determine prime cost was rated lowest by the respondents ( $\mathrm{x}=$ 4.04; $\mathrm{SD}=0.50$ ). The result further revealed that all the twelve (12) price determination skills were important for small business operation.

The analysis of variance (ANOVA) presented in Table 6 above showed that the F-ratio values of 9 out of 12 items were between 3.91 - 13.23 which are all greater than the F-critical value of 3.00 at P 0.05 level of significance. This implied that, there are significant differences in the mean ratings of the responses of the small business operators with 1 - 5 years, 6 - 10 years and above 10 years of experience on the 9 price determination skills possessed by the operators. Therefore, the null hypothesis of no significant difference was rejected.

The result of the Post Hoc test for the 9 items that are significant showed that the sources of difference for the items are small business operators with above 10 years of business experience. This implied that business operators with above 10 years of experience possessed price determination skill items 1, 4, 5, 7, 10,11 and 12 better than those with 6 years and below. 
Table 5. Mean scores, standard deviation and analysis of variance (ANOVA) of ratings of small business operators on perceived importance and expressed possession of inventory control skills according to years of experience.

\begin{tabular}{|c|c|c|c|c|c|c|c|c|c|}
\hline \multirow[t]{2}{*}{$\mathbf{S} / \mathbf{N}$} & \multirow[t]{2}{*}{ Skill Statement } & \multicolumn{2}{|c|}{$\begin{array}{l}\text { Perceived } \\
\text { Importance }\end{array}$} & \multicolumn{2}{|c|}{$\begin{array}{l}\text { Expressed } \\
\text { Possession }\end{array}$} & \multirow[t]{2}{*}{ F-Ratio } & \multirow[t]{2}{*}{ F-Critical } & \multirow[t]{2}{*}{ Ho } & \multirow{2}{*}{$\begin{array}{l}\text { Post Hoc Test } \\
\text { (scheffe) }\end{array}$} \\
\hline & & $\mathrm{X} 1$ & SD1 & $\mathrm{X} 2$ & SD2 & & & & \\
\hline 1 & $\begin{array}{l}\text { Calculate the minimum stock level to avoid stock } \\
\text { out }\end{array}$ & 4.42 & 0.08 & 2.67 & 0.89 & 5.71 & 3 & $\mathrm{~s}$ & Above 10 yrs \\
\hline 2 & $\begin{array}{l}\text { Calculate the maximum stock level to determine } \\
\text { economic order quantity }\end{array}$ & 4.39 & 0.79 & 2.38 & 0.89 & 2.63 & 3 & $\mathrm{~s}$ & $6-10$ yrs \\
\hline 3 & $\begin{array}{l}\text { Calculate the reorder level of stock to determine } \\
\text { the maximum usage of stock and the lead time }\end{array}$ & 4.29 & 0.87 & 1.95 & 0.87 & 1.54 & 3 & Ns & \\
\hline 4 & $\begin{array}{l}\text { Calculate the lead time to determine the period of } \\
\text { reordering of stock }\end{array}$ & 4.58 & 0.73 & 2.85 & 0.85 & 7.96 & 3 & $\mathrm{~s}$ & Above 10 yrs \\
\hline 5 & $\begin{array}{l}\text { Use carrying cost and reordering cost to calculate } \\
\text { the total cost of stock }\end{array}$ & 4.48 & 0.57 & 2.37 & 1 & 0.56 & 3 & $\mathrm{~s}$ & Above 10 yrs \\
\hline 6 & $\begin{array}{l}\text { Period stock taking to determine the quantity of } \\
\text { items in the store }\end{array}$ & 4.33 & 0.78 & 2.37 & 1.16 & 3.52 & 3 & Ns & \\
\hline 7 & $\begin{array}{l}\text { Use continuous stock taking to determine the } \\
\text { quantity of items in the store }\end{array}$ & 4.43 & 0.66 & 3.97 & 0.99 & 1.57 & 3 & $\mathrm{~s}$ & Above 10 yrs \\
\hline 8 & Use good storage facilities to store inventories & 4.19 & 0.79 & 2.46 & 0.73 & 1.68 & 3 & Ns & \\
\hline 9 & $\begin{array}{l}\text { Place order for moving inventory at the right } \\
\text { quantity and quality }\end{array}$ & 4.05 & 0.85 & 1.97 & 0.79 & 17.51 & 3 & $\mathrm{~s}$ & $6-10 \mathrm{yrs}$ \\
\hline 10 & Keep buffer stock to avoid the lost of customers & 4.53 & 0.58 & 2.38 & 0.86 & 27.87 & 3 & s & Above 10 yrs \\
\hline 11 & Record the issuance and usage of inventory & 4.33 & 0.78 & 1.94 & 1.04 & 5.02 & 3 & s & Above 10 yrs \\
\hline 12 & Calculate carrying cost to minimize lost & 4.52 & 0.79 & 3.52 & 0.97 & 15.3 & 3 & $\mathrm{~s}$ & Above 10 yrs \\
\hline 13 & $\begin{array}{l}\text { Set inventory prices as low as possible to attract } \\
\text { customers }\end{array}$ & 4.48 & 0.5 & 2.45 & 0.59 & 3.25 & 3 & $\mathrm{~s}$ & Above 10 yrs \\
\hline 14 & $\begin{array}{l}\text { Take physical count of inventory to manage } \\
\text { deterioration and obsolesce }\end{array}$ & 4.52 & 0.5 & 1.91 & 0.56 & 12.16 & 3 & s & $6-10 \mathrm{yrs}$ \\
\hline 15 & Store moving inventory to minimize holding cost & 4.38 & 0.66 & 2.49 & 0.66 & 1.16 & 3 & Ns & \\
\hline 16 & $\begin{array}{l}\text { Frequent check of stock to prevent and control } \\
\text { fraud }\end{array}$ & 4.28 & 0.63 & 2.51 & 0.69 & 15.42 & 3 & $\mathrm{~s}$ & Above 10 yrs \\
\hline
\end{tabular}

F-tab $=3.00, \mathrm{df}=2$ and 266, $\mathrm{P}>0.05$.

\section{Discussion of Findings}

The findings of this study as regards record-keeping skills needs showed that the skills possessed by small business operators in Anambra state are significantly lower than the level at which the skills are rated as important for operating small businesses. The skills include: debiting cash sales in the cash book and post entry to credit side of the ledger, crediting cash purchases in the cash book and debiting the ledger account, posting the sundry sales to ledger, recording goods purchased on credit in the purchases day book, posting the sundry purchases in the ledger account, using return inwards book to record goods returned by customers, entering transactions to subsidiary book from source documents, maintaining store ledger account, using bin card to record stock movement, recording goods sent back to suppliers in the return outward book and posting transactions to various accounting books as they occur. It was also observed that operators with HND/B.Sc and those with $6-10$ years of experience tend to possess record-keeping skills than those with lower qualifications and operators with 1 - 5 years of experience.

Good record keeping is essential for success of business because it supports all communication and decision making. Ekwere [25] asserted that businesses are established for trading and profit making, and the success of a business depends to a large extent on the accuracy of records keeping. Good record keeping deals with financial management of a business enterprise. Hence the findings of this study on recording keeping is in agreement with the findings of Otah [26] who found from his study on the working capital management of small scale enterprises in Owerri metropolis of Imo State that there were inadequate and up-to-date record keeping among the 
Table 6. Mean scores, standard deviation and analysis of variance (ANOVA) of ratings of small business operators on perceived importance and expressed possession of price determination skills according to years of experience.

\begin{tabular}{|c|c|c|c|c|c|c|c|c|c|}
\hline \multirow[t]{2}{*}{$\mathbf{S} / \mathbf{N}$} & \multirow[t]{2}{*}{ Skill Statement } & \multicolumn{2}{|c|}{$\begin{array}{l}\text { Perceived } \\
\text { Importance }\end{array}$} & \multicolumn{2}{|c|}{$\begin{array}{l}\text { Expressed } \\
\text { Possession }\end{array}$} & \multirow[t]{2}{*}{ F-Ratio } & \multirow[t]{2}{*}{ F-Critical } & \multirow[t]{2}{*}{ Ho } & \multirow{2}{*}{$\begin{array}{l}\text { Post Hoc Test } \\
\text { (scheffe) }\end{array}$} \\
\hline & & $\mathbf{X 1}$ & SD1 & $\mathrm{X} 2$ & SD2 & & & & \\
\hline 1 & Calculate cost per unit of item & 4.35 & 0.66 & 2.48 & 0.9 & 11.49 & 3 & $\mathrm{~s}$ & Above 10 yrs \\
\hline 2 & Calculate the total cost of product or service & 4.34 & 0.68 & 2.5 & 0.85 & 5.67 & 3 & s & $6-10 \mathrm{yrs}$ \\
\hline 3 & compute prime cost by adding direct costs & 4.23 & 0.87 & 3.79 & 0.68 & 1.91 & 3 & Ns & \\
\hline 4 & $\begin{array}{l}\text { Calculate overheads by subtracting the sum of factory, } \\
\text { administrative, selling and distribution expenses from } \\
\text { total cost }\end{array}$ & 4.35 & 0.63 & 2.36 & 0.73 & 12.24 & 3 & s & Above 10 yrs \\
\hline 5 & Add direct wages to determine prime cost & 4.04 & 0.5 & 2.89 & 0.82 & 4.82 & 3 & $\mathrm{~s}$ & Above 10 yrs \\
\hline 6 & $\begin{array}{l}\text { Calculate profit or loss by subtracting the cost of sale } \\
\text { from total sales }\end{array}$ & 4.33 & 0.71 & 2.51 & 0.85 & 1.67 & 3 & Ns & \\
\hline 7 & $\begin{array}{l}\text { Identify and allocate direct cost by adding direct and } \\
\text { indirect materials, wages indirect expenses }\end{array}$ & 4.52 & 0.5 & 2.61 & 0.91 & 13.23 & 3 & $\mathrm{~s}$ & Above 10 yrs \\
\hline 8 & $\begin{array}{l}\text { Aggregate direct material cost, direct wages and direct } \\
\text { expenses to arrive at prime cost }\end{array}$ & 4.28 & 0.69 & 2.18 & 1.05 & 2.23 & 3 & Ns & \\
\hline 9 & $\begin{array}{l}\text { Aggregate indirect material cost, indirect wages and } \\
\text { indirect expenses to arrive at overhead cost }\end{array}$ & 4.17 & 0.5 & 3.96 & 1.14 & 3.91 & 3 & $\mathrm{~s}$ & $6-10 \mathrm{yrs}$ \\
\hline 10 & Calculate the selling price using mark-up system & 4.52 & 0.5 & 2.2 & 1.03 & 8.43 & 3 & $\mathrm{~s}$ & Above 10 yrs \\
\hline 11 & $\begin{array}{l}\text { Calculate the selling price by deducting the discount } \\
\text { allowed to arrive at agreed invoice price }\end{array}$ & 4.62 & 0.57 & 2.42 & 0.96 & 6.93 & 3 & $\mathrm{~s}$ & Above 10 yrs \\
\hline 12 & $\begin{array}{l}\text { Subtract selling expenses from gross profit to arrive at } \\
\text { net profit }\end{array}$ & 4.57 & 0.66 & 2.44 & 0.7 & 4.45 & 3 & s & HND/B.Sc \\
\hline
\end{tabular}

$\mathrm{F}-\mathrm{tab}=3.00, \mathrm{df}=2$ and 266, $\mathrm{P}>0.05$.

small and medium scale enterprise operators in the area.

The findings of this study on the inventory control skills needs of small business operators showed that the skills possessed by small business operators in Anambra state are also significantly lower than the level at which the skills are rated important for operating small businesses. These inventory control skills include: calculating the minimum stock level to avoid stock outs, calculating the maximum stock level to determine economic order quantity, calculating the reorder level of stock to determine the maximum usage of stock and the lead time, calculating the lead time to determine the period of reordering of stock, using carrying cost and ordering cost to calculate the total cost of stock, using period stock taking to determine the quantity of items in the store, placing order for moving inventory at the right quantity and quality, recording the insurance and usage of inventory, calculating carrying cost to minimize loss, setting inventory prices as low as possible to attract customers and storing moving inventory to minimize holding cost.

Stock control is a stock management process which is concerned mainly with the identification of needed stock, quality and quantity, identifying the suppliers and the best prices obtainable, identifying the best conveyance method to reduce cost and breakage among others. The findings of this study on stock control agreed with the submission of Agara [27] who reported that stock control practices are inventory management practices that are often times lacking among small and medium scale business owners, hence their high rate of business failure. In addition, the findings of this study is also in conformity with that of Jhingan [28] who revealed the inability of most operators of the SMEs to adopt adequate stock and cash management practices to check and maintain balances in stock level. Therefore, it is imperative that small business operators should effectively manage their stock for the success of their businesses.

The findings of this study as regards price determination skills revealed that both rural and urban operators needed the skills for better operations of their business. Lucey [8] stated that pricing decision suffers from lack of accurate and relevant information. Setting prices for goods and services involves an interesting interaction of several factors. The price must be sufficient to exceed the product and period costs and earn a desirable profit. The skills include: calculating cost per unit of item, computing prime cost by adding direct costs, calculating 
overheads by subtracting the sum of factory, administrative, selling and distribution expenses for total cost, calculating profit or loss by subtracting the cost of sales from total sales, identifying and allocating direct cost by adding direct and indirect materials, wages and indirect expenses, aggregating direct material cost, direct wages and direct expenses to arrive at prime cost, aggregating indirect material cost, indirect-wages and indirect expenses to arrive at overhead cost, calculating the selling price using mark-up system and calculating the selling price by deducting the discount allowed to arrive at agreed invoice price.

Okafor [29] found that small business operators do not utilized pricing strategies such as the use of skimming method, the use of complementary pricing for two different grades of products, the use of discount and allowances to customers of the products, calculating overheads by subtracting the sum of factory and profit or loss by subtracting the cost of sales from total sales. The findings of this study is also in consonance with the result of Ugwu [30] who found that the marketing of agricultural products in Nsukka LGA have not been effective because of many factors among which poor pricing practices are included.

\section{Conclusion}

This study was carried out to determine the record-keeping and inventory control skills needs of small business operators in Anambra State. The study identified 15 record-keeping skills and 16 inventory control skills and compared the level of perceived importance of the skills with the level of expressed possession of the skills by the small operators. It was found that record-keeping and inventory control skills possessed by the small business operators in the State were significantly very low. On the other hand, the respondents rated all the 15 record-keepings and 16 inventory control skills as important. Based on these findings, the study concluded that some of the factors responsible for the frequent business failure among the small business operators in the state are inadequate record keeping and poor inventory control skills. These results indicated that the small business operators need record-keeping, inventory control and price determination skills for successful business operation.

\section{Recommendations}

Based on the findings of the study, the following recommendations are:

1) Operators of small businesses in the state should be subjected to short training on record-keeping, inventory control and price determination skills needed for successful business operations.

2) Regular workshops should be organised by experts and academics to sensitize the small business operators on the importance of record-keeping, inventory control and price determination skills.

3) The federal and state governments should ensure the provision of enabling business environment for growth and development of small and medium business operators if they must continue in their role of employment creation and poverty reduction in the country and Anambra State in particular. This should be achieved through the provision of soft loans to keep the small business operators in business.

\section{References}

[1] Murthy, A. and Gurusamy, S. (2009) Cost Accounting. 2nd Edition, McGraw-Hill, New Delhi.

[2] Horngren, C.T., Datar, S.M., Rajan, M. and Ittner, C. (2009) Cost Accounting: Managerial Emphasis. 13th Edition, Pearson Education Inc., Upper Saddle River.

[3] Clifford, B., Kenneth, M., Pearce, L. and Kelly, C. (2000) How to Organize and Operate a Small Business. 5th Edition, Prentice Hall, Englewood.

[4] Ndulue, J.C. (2002) Importance of Accounting Information for Small Scale Enterprises. Certified National—Accountant Publication, Lagos.

[5] Osuala, E.C. (2004) Introduction to Research Methodology. Africana-Fep Publishers Ltd., Onitsha.

[6] Osuala, E.C. (2005) Principles and Practices of Small Business Management in Nigeria. Cheston Agency Ltd., Enugu.

[7] Bessong, P.K. (2005) Cost and Management Accounting-Basic Theories, Problems and Solutions. EL-Sapphire Ltd., Lagos.

[8] Lucey, T. (2009) Costing. 7th Edition, South-Western Cengage Learning, London.

[9] Osuala, E.C. (2004) Principles and Practices of Small Business Management in Nigeria. Cheston Agency Ltd., Enugu.

[10] Ikpe, D.N. (2006) Foundations of Business Accounting in Nigeria. Keny and Brothers Enterprises, Enugu. 
[11] Osuala, E.C. (2001) Introduction to Research Methodology. Africana-Fep Publishers Ltd., Onitsha.

[12] Asuquo, E.E. (2011) Perception of Business Education Lecturers in Colleges of Education on the Influence of Retail Store Variable on Impulse Buying Behavior of Consumers in North-West Nigeria. Unpublished Doctorial Thesis, University of Nigeria, Nsukka.

[13] Kotler, P. and Keller, K.L. (2005) Marketing Management. 12th Edition, Prentice-Hall of India Private Limited, New Delhi.

[14] Obi, C.A. (2011) Elements of Business. 3rd Edition, De-Verge Agency Ltd., Enugu.

[15] Okoro, F.N. (2006) Strategies for Improving the Financial Management Practices of Small and Medium Scale Entrepreneurs in Niger Delta of Nigeria. Unpublished Ph.D. Thesis, Department of Vocational Teacher Education, University of Nigeria, Nsukka.

[16] Nnachi, R.O. (2007) Advanced Psychology of Learning and Scientific Enquiries. TOTAN Publishers, Owerri.

[17] Ayozie, D.O. (2004) The Role of SMEs in the Development of Nigerian Economy. Development Universal Consortia, Ikot-Ekpene.

[18] Adekola, A.A. (2010) Small Business and Entrepreneurial Skills. Seetop Computers and Printing, Ibadan.

[19] Longman (2007) Longman Dictionary of Contemporary English. New Edition, Pearson Educational Limited, England.

[20] Oyekanmi, R. (2003) Concepts of Equity Financing and Its Implication for SMEIS. Central Bank of Nigeria Seminar on Small and Medium Industries Equity Scheme (SMIEIS). CBN Training Centre, Lagos.

[21] NASME (2003) The Small and Medium Enterprises: Prospects and Perspectives. Amanda Communication Ltd., Lagos.

[22] NCI (2003) Small Business in Nigeria. NCI, Bethesda.

[23] Udechukwu, F.N. (2003) Survey of Small and Medium Scale Industries and Others Potential in Nigeria: Central Bank of Nigeria Seminar on Small and Medium Industries Equity Scheme (SMIEIS). CBN Training Centre, Lagos.

[24] Scott, D.F. and Moore, L.J. (2003) Simulating Cash Budgets. Journal of Systems Management, 10, 28-33.

[25] Ekwere, A.B. (2005) Contemporary Accounting. AFLON Limited, Abuja.

[26] Otah, O.N. (2000) The Working Capital Management of Small Scale Enterprises. A Case Study of Owerri Metropolis. Unpublished MBA Thesis, University of Nigeria, Nsukka.

[27] Agara, I.G. (2005) Management Accounting: Effective Management Tool. ETI-KIND and Company Limited, Lagos.

[28] Jhingan, M.L. (2004) Microeconomic Theory. 5th Revised and Enlarged Edition, Vrinda Publications Ltd., Delhi.

[29] Okafor, C.A. (2010) Extent of Application of Pricing Strategies by Small and Medium Scale Operators in Cross River State. International Journal of Business Administration, 3, 235-248.

[30] Ugwu, N.C. (2005) Marketing of Agricultural Products in Nsukka L.G.A.: A Case Study of Yam, Garri, Rice and Beans. An Unpublished Thesis of the Department of Marketing, University of Nigeria, Enugu. 